\title{
Application for Selection of Student Final Project Supervisors Based on the Selected Category and Expertise of Lecturers Using the Naive Bayes Classifier Method
}

\author{
Muhamad Ikhsanudin ${ }^{1}$, Yuda Irawan ${ }^{2 *}$ \\ ${ }^{1,2}$ Department of Information System, STMIK Hang Tuah Pekanbaru, Pekanbaru, Indonesia \\ Email: 1ikhsan.si02@gmail.com, ${ }^{2}$ yudairawan89@gmail.com \\ *Corresponding Author
}

\begin{abstract}
At the end of the task the supervisor has an important role for the success achieved and graduation of students. For this reason, ideal supervisors are needed for students. As discussed in the STMIK Hang Tuah Pekanbaru in the process of submitting the title of this thesis, so are some of the problems that arise, namely regarding the matter of coaching because the process is still using conventional methods that is based on personal knowledge of the Head of Study Program, the difficulty of the development process of submitting the Student's final position for difficulties check the final supervisor's assignment. The application of selecting the final project supervisor for students is the solution of the debate. The supervisor lecturer recommendation system that can utilize the naïve bayes classifier algorithm as a determinant of the probability of the lecturer results students can choose. Naive Bayes is a prediction technique based on simple probabilities based on the application of the Bayes theorem (Bayes rule) with a strong assumption of independence. The selection is based on the final criteria for the assignment and expertise of the lecturer. From the application of this recommendation is obtained from the recommendations of supervisors in accordance with the concept of the student's final project. With reference data, training and Bayes rules obtained sufficient results to satisfy students in getting a supervisor who is in accordance with the topic of the student's final project.
\end{abstract}

Keywords- naïve bayes classifier, decision support system, supervisory lecturer selection application

\section{INTRODUCTION}

Students ask the supervisor of the final project that can be a means of consultation in the process of working on the student's final project was studied by leng [1]. Thus students are expected to be able to do the final project well, smoothly and finish on time was studied by qin [2].

One of the graduation requirements for STMIK Hang Tuah Pekanbaru students, be it Information Systems Study Program or Informatics Engineering Study Program, is to make a scientific paper in the form of a thesis which is the final project was studied by Solanki [3]. In preparing the final project, students really need a supervisor as a place to consult and discuss in the progress and completion of student final assignments was studied by song [4]. Supervisors should be people who master the field that is the topic of student final assignments, so that the process of compiling and mentoring between students and supervisors can run optimally was studied by irawan [5].

The accuracy in selecting supervisors in the process of preparing student final assignments plays an important role in determining the success and graduation of student final assignments was studied by varuna [6]. Students need an ideal final assignment supervisor, namely a supervisor who can provide input, direction, explanation, and fully understand the themes, topics, and case studies in student final assignments was studied by chandrasekar [7].

The process of determining the student's final assignment supervisor at STMIK Hang Tuah Pekanbaru is currently the task of the Head of Study Program and is still using conventional methods was studied by muhardi [8]. Where students submit the title of the final project in the system then selected based on the criteria for the title of the student's final project and if the title of the student's final project is accepted, the Head of the Study Program will immediately determine the student supervisor based on personal knowledge of the specifications and competence of the lecturer's expertise in accordance with the topic of the student's final project was studied by wang [9].

Based on the process of determining the student's final assignment supervisor, there are still problems and obstacles that often lead to less than optimal decision results were studied by bhakre [10]., namely the possibility of errors in determining the student's final assignment supervisor because the Head of Study Program only relies on personal knowledge of the specifications and competence of the lecturer was studied by netti [11].

This will have bad consequences for the preparation of student final assignments, if the supervisor determined by the Head of the Study Program is not appropriate and does not master the topic of the student's final project under his guidance was studied by Irawan [12]. The consultation process will not run optimally and the results of the student's final project will be unsatisfactory was studied by baati [13]. 
Even though in the process of finalizing the final project, students really need a supervisor who is able to provide calm and enlightenment about the problems experienced by students was studied by wu [14], because in the preparation of final assignments students will experience the peak situation in the lecture process which is able to put a lot of pressure on students' thoughts and feelings was studied by lenardo [15].

As is the case with other universities, STMIK Hang Tuah Peknabaru also implements a student quota system which will be guided by each lecturer who is assigned as the supervisor for student final assignments was studied by qiang [16].

The calculation of Lecturer Workload is based, among others, on the main activities of the lecturer which include: a) Planning, implementing, and controlling the learning process; b) Implementation of evaluation of learning outcomes; c) Guidance and training; d) Research; and e). Community service was studied by badriyah [17]. Activities in the form of implementing additional tasks; and supporting activities was studied by Irawan [18]. Lecturer Workload is at least 40 hours / week, or the equivalent of managing 12 (twelve) credits (Tridarma PT) per semester for lecturers who do not get additional assignments was studied by wahyuni [19]. Meanwhile, for lecturers who get additional assignments, the workload on the lecturers' main activities is adjusted to the amount of the additional assignment load was studied by adi [20]. The workload of the lecturer in guiding structured research in the framework of the preparation of a thesis / final project, thesis, dissertation, or other equivalent design / art / form is a maximum of 10 (ten) students was studied by Irawan [21].

The process of preparing student final assignments is very influential on the final results achieved was studied by seth [22]. At STMIK Hang Tuah, students are required to be able to produce a tangible result from the final project that has been compiled was studied by ordila [23]. If in the design process the student is not mature and the ability of the supervisor who is not in his / her field will produce a real output that is not optimal was studied by fonda [24], the worst possibility is that the student will be unable to complete the final project and will hinder graduation was studied by aksoy [25].

So it is very important to determine the supervisor of the student's final project according to the theme of the student's final project and the scientific field of the supervisor was studied by wahyuni [26]. So that the process of preparation and consultation between students and supervisors runs optimally and the final results of the student's final project can be achieved and satisfying was studied by seref [27].

\section{METHODS}

The method of making applications in this study uses a prototype method which consists of several stages. The stages in Prototyping are as follows:

1. Collection of needs, based on the problem of selecting the student's final assignment supervisor at STMIK Hang Tuah Pekanbaru and designing the application format to be made.

2. Build prototyping, at this stage build a temporary design of the application to be made and focus on presentation.
The system design process is carried out through three processes, namely:

a. Process Modeling

Process modeling is carried out using Use Case Diagrams and Sequence Diagrams.

b. Data Modeling

Data modeling is done using Class Diagrams.

c. Interface Design

The design of the system interface for users is done using the features available in Microsoft Word.

3. Evaluation of prototyping, at this stage an evaluation is carried out based on the prototyping that has been built for application users. If it is appropriate then step 4 will be taken. If not, the prototyping is revised by repeating steps 1, 2, and.

4. Encoding the system, the stage of translating data or solving problems that have been designed into a specific programming language. In this study, coding was carried out using the PHP programming language and MySQL database.

5. Testing the system, Testing the system that has been made to prove how accurate the system is designed. The author tests the features of the system, whether it is running according to the design or not. If there are still errors in the program, it will return to the manufacturing process. Testing is done by testing black box to demonstrate the function of the system being operated.

6. System Evaluation, the user evaluates whether the finished system is as expected. If yes, step 7 is done, if not, repeat steps 4 and 5 .

7. Using the system, at this stage the application is ready for use.

\section{IMPLEMENTATION}

In this implementation chapter will display the pages contained in theapplication monitoring housingthat has been designed and made as described in the previous chapter. This stage is an activity of making a system or application using the help of software or hardware in

accordance with the analysis. and design to produce a working system. Furthermore, an evaluation of the test results is carried out, if the test results haveProject.

\section{Display The Login}

Figure 1 is the login display on the Application for Student Supervisory Lecturer Selection Based on the Choice Category and Lecturer Expertise Using the Naïve Bayes Classifier Method. The display of the login menu is shown in Figure 1.

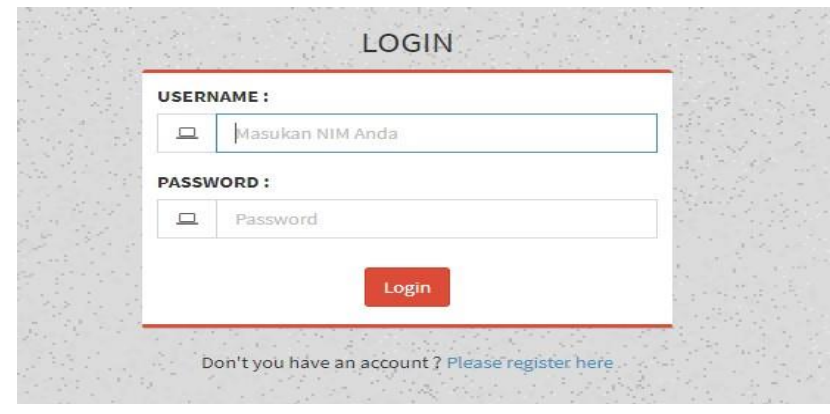

Fig.1. Display the login 
The image above is the Login display which is the display after registering from the Application. Where before logging in, you must enter the username and password that was previously registered.

\section{Display of Student User Menu for Submission of Results.}

Figure 2 is a display of the menu for Student Submission of Results.

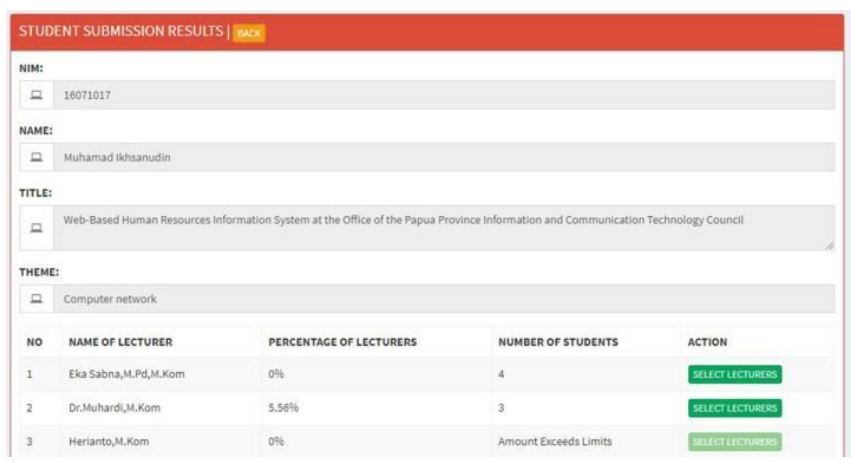

Fig.2. Display submission of result

Figure 2 is a menu display of the results of student submissions that have been inputted previously.

\section{Training Menu Display}

Figure 3 is a display of the Training Menu.

\begin{tabular}{|c|c|c|c|}
\hline \multicolumn{4}{|c|}{ TRAINING DATA | } \\
\hline no & exptrtise & Lectunerss & Action \\
\hline 1 & Computer network & Or.Muhardi, M.Kom & 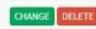 \\
\hline 2 & Computer network & vilisman, M.Kom & Couscer matrit \\
\hline 3 & Operating system & Yulisman,M...xom & CHASGE Delist \\
\hline 4 & Operating system & Dr.Muhard, M.Kom & 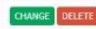 \\
\hline 5 & Data Mining & Ela sabna,M.Pd,M.,.Kom & 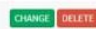 \\
\hline 6 & Data Mining & Hendy Fonda, M.Kom & 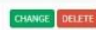 \\
\hline 7 & Decision Support 5 Sstem & Hendy Fonda, MKom & 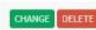 \\
\hline 8 & Expert system & Ela sabra,M.Pd,M...kom & वusce Detre \\
\hline
\end{tabular}

Fig.3. Display menu display

Figure 3 is a training application data display consisting of Expertise and Lecturers.

\section{Lecturer Traffic Menu Display}

Figure 4 is a display of the Lecturer Traffic Menu in the application which can be seen as follows. Picture above is a display of lecturer traffic at STMIK Hang Tuah Pekanbaru.

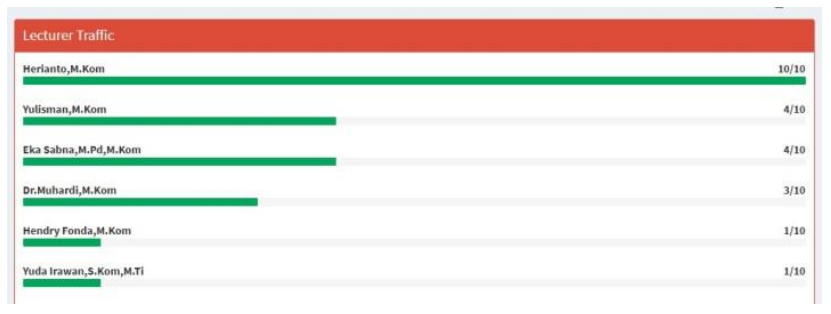

Fig.4. Display lecturer traffic menu display

\section{Display of Expertise Probability}

Figure 6 is a display of the Expertise Probability Menu of lecturers that has been inputted in the Application for Selection of Student Final Project Supervisors Based on the Choices and Expertise Categories of Lecturers Using the Naïve Bayes Classifier Method.

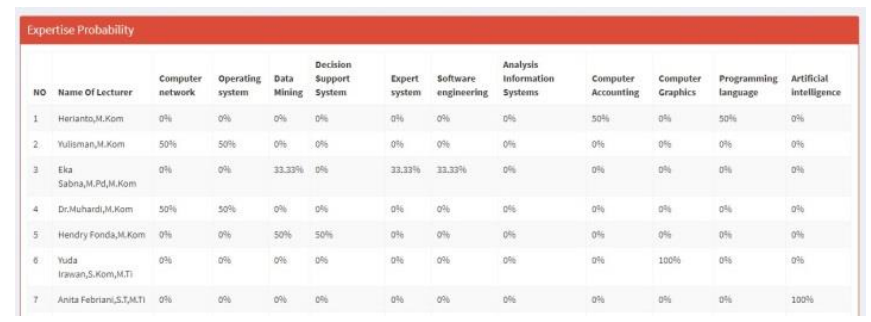

Fig.5. Display of Expertise Probability

Figure 5 is a display of the probability menu of STMIK Hang Tuah Pekanbaru lecturers.

\section{Lecturer Probability Menu Display}

Figure 6 is a display of the Lecturer Probability Menu.

\begin{tabular}{|c|c|c|}
\hline \multicolumn{3}{|c|}{ Lecturer Probability } \\
\hline No & Naem of Lecturer & Probability \\
\hline 1 & Herianto,M.Kom & $12.11 \%$ \\
\hline 2 & rulisman,M.Kom & $12.11 \%$ \\
\hline 3 & Eka Sabna,M.pe,M.,.Kom & 16.6796 \\
\hline 4 & Or.Muhardi,im.Kom & $11.11 \%$ \\
\hline 5 & Hendry Fonda,M.Kom & $11.11 \%$ \\
\hline 6 & Yuda trawan,, Kom, M.M. & 5.5696 \\
\hline , & Anita Febranis,ST,M.TI & $5.56 \%$ \\
\hline 8 & Yulanda,M,Kom & $5.56 \%$ \\
\hline , & Rila Metyant, M.Kom & $5.56 \%$ \\
\hline
\end{tabular}

Fig.6. Lecturer probability menu display

The picture in Figure 6 is a display of the probability of a lecturer consisting of the name of the lecturer and the probability.

\section{Viewing Menu Display}

Figure 7 is a display of the Submission Menu.

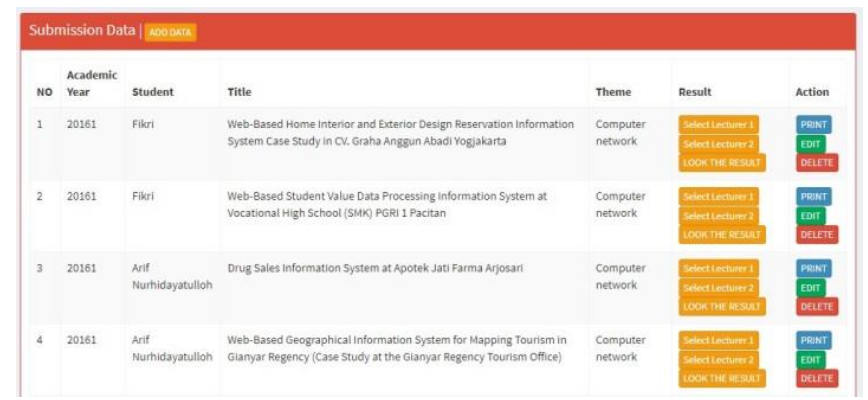

Fig.7. Viewing menu display

The picture in Figure 7 is a display of the Submission Menu which is used by students in submitting titles to this application.

\section{Sample Submission}

Table 1 is the sample submission in the research.

TABLE I. SAMPLE SUBMISSION

\begin{tabular}{l|l|l} 
No & Lecturer Expertise & Lecturer Name
\end{tabular}

Muhamad Ikhsanudin, Application for Selection of Student Final Project Supervisors Based on the Selected Category and Expertise of Lecturers Using the Naive Bayes Classifier Method 


\begin{tabular}{|c|c|c|}
\hline No & Lecturer Expertise & Lecturer Name \\
\hline 1 & Computer network & Dr.Muhardi,M.Kom \\
\hline 2 & Computer network & Yulisman,M.Kom \\
\hline 3 & Operating system & Dr.Muhardi,M.Kom \\
\hline 4 & Operating system & Yulisman,M.Kom \\
\hline 5 & Data Mining & $\begin{array}{c}\text { Eka } \\
\text { Sabna,M.Pd,M.Kom }\end{array}$ \\
\hline 6 & Data Mining & Hendry Fonda,M.Kom \\
\hline 7 & $\begin{array}{l}\text { Decision Support } \\
\text { System }\end{array}$ & Hendry Fonda,M.Kom \\
\hline 8 & Expert system & $\begin{array}{c}\text { Eka } \\
\text { Sabna,M.Pd,M.Kom }\end{array}$ \\
\hline 9 & $\begin{array}{c}\text { Software } \\
\text { engineering }\end{array}$ & $\begin{array}{c}\text { Eka } \\
\text { Sabna,M.Pd,M.Kom }\end{array}$ \\
\hline 10 & $\begin{array}{c}\text { Software } \\
\text { engineering }\end{array}$ & $\begin{array}{c}\text { Uci } \\
\text { Rahmalisa,S.Kom,M.Ti }\end{array}$ \\
\hline 11 & $\begin{array}{c}\text { Analysis } \\
\text { Information } \\
\text { Systems }\end{array}$ & Rika Melyanti,M.Kom \\
\hline 12 & $\begin{array}{c}\text { Analysis } \\
\text { Information } \\
\text { Systems }\end{array}$ & $\begin{array}{c}\text { Akhmad } \\
\text { Zulkifli,M.Kom }\end{array}$ \\
\hline 13 & $\begin{array}{l}\text { Computer } \\
\text { Accounting }\end{array}$ & Herianto,M.Kom \\
\hline 14 & Computer Graphics & $\begin{array}{c}\text { Refni } \\
\text { Wahyuni,S.Kom,M.Ti }\end{array}$ \\
\hline 15 & Computer Graphics & $\begin{array}{c}\text { Yuda } \\
\text { Irawan,S.Kom,M.Ti } \\
\end{array}$ \\
\hline 16 & $\begin{array}{l}\text { Programming } \\
\text { language }\end{array}$ & Herianto,M.Kom \\
\hline 17 & $\begin{array}{c}\text { Programming } \\
\text { language }\end{array}$ & Yulanda,M.Kom \\
\hline 18 & $\begin{array}{c}\text { Artificial } \\
\text { intelligence }\end{array}$ & $\begin{array}{c}\text { Anita } \\
\text { Febriani,S.T,M.Ti } \\
\end{array}$ \\
\hline
\end{tabular}

Student thesis theme or the expertise of the elective final assignment supervisor lecturer $=$ Software Engineering.

First of all, the posterior supervisor of the final assignment must be searched for the sample.

$$
\begin{aligned}
& \text { P(Herianto,M.Kom }) \\
& =2 / 18 / 100=11.11 \% \\
& \text { P(Yulisman,M.Kom }) \\
& =2 / 18 / 100 \quad=11.11 \% \\
& \text { P(Eka Sabna,M.Pd,M.Kom) } \\
& =3 / 18 / 100 \quad=16.67 \% \\
& \text { P(Dr.Muhardi,M.Kom) } \\
& =2 / 18 / 100 \quad=11.11 \% \\
& \text { P(Hendry Fonda,M.Kom) } \\
& =2 / 18 / 100 \quad=11.11 \% \\
& \text { P(Yuda Irawan,S.Kom,M.Ti) } \\
& =1 / 18 / 100 \quad=5.56 \% \\
& \text { P(Anita Febriani,S.T,M.Ti) } \\
& =1 / 18 / 100 \quad=5.56 \% \\
& \text { P(Yulanda,M.Kom) } \\
& =1 / 18 / 100 \quad=5.56 \% \\
& \text { P(Rika Melyanti,M.Kom) } \\
& =1 / 18 / 100 \quad=5.56 \%
\end{aligned}
$$

P(Akhmad Zulkifli,M.Kom)

$=1 / 18 / 100 \quad=5.56 \%$

P(Refni Wahyuni,S.Kom,M.Ti)

$=1 / 18 / 100 \quad=5.56 \%$

P(Uci Rahmalisa,S.Kom,M.Ti)

$=1 / 18 / 100 \quad=5.56 \%$

Next, you must first look for the Posterior, the supervisor of the student's final project with the skills of the lecturer for the sample.

$\mathrm{P}($ Herianto,M.Kom| Software engineering)

$=2 / 0 / 100=0 \%$

$\mathrm{P}($ Yulisman,M.Kom | Software engineering)

$=2 / 0 / 100=0 \%$

$\mathrm{P}($ Eka Sabna,M.Pd,M.Kom | Software engineering)

$=3 / 1 / 100 \quad=0.33 \%$

P(Dr.Muhardi,M.Kom | Software engineering)

$=2 / 0 / 100 \quad=0 \%$

$\mathrm{P}$ (Hendry Fonda,M.Kom | Software engineering)

$=2 / 0 / 100 \quad=0 \%$

$\mathrm{P}$ (Yuda Irawan,S.Kom,M.Ti | Software engineering)

$=2 / 0 / 100 \quad=0 \%$

$\mathrm{P}($ Anita Febriani,S.T,M.Ti | Software engineering)

$=2 / 0 / 100 \quad=0 \%$

$\mathrm{P}$ (Yulanda,M.Kom | Software engineering)

$=2 / 0 / 100 \quad=0 \%$

P(Rika Melyanti,M.Kom | Software engineering)

$=2 / 0 / 100 \quad=0 \%$

P(Akhmad Zulkifli,M.Kom | Software engineering)

$=2 / 0 / 100 \quad=0 \%$

$\mathrm{P}($ Refni Wahyuni,S.Kom,M.Ti | Software engineering $)=$ $2 / 0 / 100=0 \%$

$\mathrm{P}($ Uci Rahmalisa,S.Kom,M.Ti | Software engineering) = $1 / 1 / 100=100 \%$

Furthermore, all probability data are multiplied based on the data from the final assignment supervisor for the sample.

Posterior(Herianto,M.Kom)

$=\mathrm{P}($ Herianto,M.Kom $) * \mathrm{P}($ Herianto,M.Kom $\mid$ Software

engineering)

$=11.11 \% * 0 \%=0 \%$

Posterior(Yulisman,M.Kom)

$=\mathrm{P}($ Yulisman,M.Kom $) * \mathrm{P}($ Yulisman, M.Kom|Software engineering)

$=11.11 \% * 0 \%=0 \%$

Posterior(Eka Sabna,M.Pd,M.Kom)

$=$ P(EkaSabna,M.Pd,M.Kom)*P(EkaSabna,M.Pd,M.Kom|

Software engineering)

$=16.67 \% * 33.33 \%=5.56 \%$

Posterior(Dr.Muhardi,M.Kom)

$=\mathrm{P}($ Dr.Muhardi,M.Kom $) * \mathrm{P}($ Dr.Muhardi,M.Kom $\mid$ Software engineering)

$=11.11 \% * 0 \%=0 \%$

Posterior(Hendry Fonda,M.Kom)

Muhamad Ikhsanudin, Application for Selection of Student Final Project Supervisors Based on the Selected Category and Expertise of Lecturers Using the Naive Bayes Classifier Method 
$=\mathrm{P}($ Hendry Fonda,M.Kom)*P(Hendry Fonda,M.Kom

Software engineering)

$=11.11 \% * 0 \%=0 \%$

Posterior(Yuda Irawan,S.Kom,M.Ti)

$=$ P(YudaIrawan,S.Kom,M.Ti)*P(YudaIrawan,S.Kom,M.Ti

Software engineering)

$=5.56 \% * 0 \%=0 \%$

Posterior(Anita Febriani,S.T,M.Ti)

$=\mathrm{P}($ AnitaFebriani,S.T,M.Ti)*P(AnitaFebriani,S.T,M.Ti

Software engineering)

$=5.56 \% * 0 \%=0 \%$

Posterior(Yulanda,M.Kom)

$=\mathrm{P}($ Yulanda,M.Kom $) * \mathrm{P}($ Yulanda,M.Kom| Software

engineering)

$=5.56 \% * 0 \%=0 \%$

Posterior(Rika Melyanti,M.Kom)

$=\mathrm{P}($ RikaMelyanti,M.Kom $) * \mathrm{P}($ RikaMelyanti,M.Kom $\mid$

Software engineering)

$=5.56 \% * 0 \%=0 \%$

Posterior(Akhmad Zulkifli,M.Kom)

$=\mathrm{P}($ Akhmad Zulkifli,M.Kom) $* \mathrm{P}$ (Akhmad Zulkifli,M.Kom|

Software engineering) $=5.56 \% * 0 \%=0 \%$

Posterior(Refni Wahyuni,S.Kom,M.Ti)

$=\mathrm{P}($ Refni Wahyuni,S.Kom,M.Ti) * P $($ Refni

Wahyuni,S.Kom,M.Ti | Software engineering)

$=5,56 \% * 0 \% *=0 \%$

Posterior(Uci Rahmalisa,S.Kom,M.Ti)

$=\mathrm{P}($ Uci Rahmalisa,S.Kom,M.Ti $) * \mathrm{P}($ Uci

Rahmalisa,S.Kom,M.Ti | Software engineering))

$=5.56 \% * 100 \%=5.56 \%$

Then the calculation results can be obtained with the sample data Software Engineering as the theme of student thesis or the expertise of lecturers are Eka Sabna, M.Pd, M.Kom and Uci Rahmalisa S.Kom, M.Ti with a value of $5.56 \%$.

And the system will automatically calculate the number of guidance students from the supervisor, if the number of guidance students exceeds 10 students, the name of the supervisor will automatically no longer be selected as the student's chosen final assignment supervisor.

\section{CONCLUSION}

At the end of this practical work report, the author will present some conclusions that can be drawn and suggestions based on the research findings. In general, the authors conclude that the process of selecting student final assignment supervisors at STMIK Hang Tuah Pekanbaru after using the Application for Student Final Project Supervisor Selection based on the Expertise of Lecturers and the Choice Category Using the Naïve Bayes Classifier Method greatly affects the effectiveness of the process of selecting the final assignment supervisor for students at
STMIK. Hang Tuah Pekanbaru. More specifically, the authors can draw the following conclusions:

1. The application for the selection of the student's final assignment supervisor at STMIK Hang Tuah Pekanbaru was built using the appropriate calculation method and can calculate the probability of conformity between the needs of the student's final project and the supervisor.

2. This application is made based on the category of choice and expertise of lecturers at STMIK Hang Tuah Pekanbaru. There are as many as 12 lecturers who are the supervising lecturers of the final project with 11 skills of the lecturers who are friends of the students' final assignments.

3. The student's final assignment supervisor will be able to be selected by the student directly using the application based on the calculation results listed on the application, so that the selection of the student's final assignment supervisor is appropriate and appropriate to the student's needs.

\section{REFERENCES}

[1] C. Leng, S. Wang and H. Wang, "Learning Naive Bayes Classifiers with Incomplete Data," 2009 International Conference on Artificial Intelligence and Computational Intelligence, Shanghai, 2009, pp. 350-353, doi: 10.1109/AICI.2009.402.

[2] F. Qin, X. Tang and Z. Cheng, "Application and research of multi_label Naïve Bayes Classifier," Proceedings of the 10th World Congress on Intelligent Control and Automation, Beijing, 2012, pp. 764-768, doi: 10.1109/WCICA.2012.6357980.

[3] R. K. Solanki, K. Verma and R. Kumar, "Spam filtering using hybrid local-global Naive Bayes classifier," 2015 International Conference on Advances in Computing, Communications and Informatics (ICACCI), Kochi, 2015, pp. 829-833, doi: 10.1109/ICACCI.2015.7275713.

[4] Q. Song, X. Liu, H. Yuan and C. Qiu, "Naive Bayes Classifier Applied in Droplet Fingerprint Recognition," 2012 Third Global Congress on Intelligent Systems, Wuhan, 2012, pp. 152-155, doi: 10.1109/GCIS.2012.68.

[5] Irawan, Y., Fernando, Y., \& Wahyuni, R. Detecting Heart Rate Using Pulse Sensor As Alternative Knowing Heart Condition. Journal of Applied Engineering and Technological Science (JAETS), 2019, 1(1), pp 30-42.

[6] S. Varuna and P. Natesan, "An integration of k-means clustering and naïve bayes classifier for Intrusion Detection," 2015 3rd International Conference on Signal Processing, Communication and Networking (ICSCN), Chennai, 2015, pp. 1-5, doi: 10.1109/ICSCN.2015.7219835.

[7] P. Chandrasekar and K. Qian, "The Impact of Data Preprocessing on the Performance of a Naive Bayes Classifier," 2016 IEEE 40th Annual Computer Software and Applications Conference (COMPSAC), Atlanta, GA, 2016, pp. 618-619, doi: 10.1109/COMPSAC.2016.205.

[8] Muhardi, Muhardi, et al. "Design Of Web Based LMS (Learning Management System) in SMAN 1 Kampar Kiri Hilir." Journal of Applied Engineering and Technological Science (JAETS) 1.2 (2020): 70-76.

[9] Y. An, S. Sun and S. Wang, "Naive Bayes classifiers for music emotion classification based on lyrics," 2017 IEEE/ACIS 16th International Conference on Computer and Information Science (ICIS), Wuhan, 2017, pp. 635-638, doi: 10.1109/ICIS.2017.7960070.

[10] S. K. Bhakre and A. Bang, "Emotion recognition on the basis of audio signal using Naive Bayes classifier," 2016 International Conference on Advances in Computing, Communications and Informatics (ICACCI), Jaipur, 2016, pp. 2363-2367, doi: 10.1109/ICACCI.2016.7732408.

[11] K. Netti and Y. Radhika, "A novel method for minimizing loss of accuracy in Naive Bayes classifier," 2015 IEEE International Conference on Computational Intelligence and Computing Research (ICCIC), Madurai, 2015, pp. 1-4, doi: 10.1109/ICCIC.2015.7435801. 
[12] Irawan, Yuda. "Implementation Of Data Mining For Determining Majors Using K-Means Algorithm In Students Of SMA Negeri 1 Pangkalan Kerinci." Journal of Applied Engineering and Technological Science (JAETS) 1.1 (2019): 17-29.

[13] K. Baati, T. M. Hamdani and A. M. Alimi, "Diagnosis of Lymphatic Diseases Using a Naive Bayes Style Possibilistic Classifier," 2013 IEEE International Conference on Systems, Man, and Cybernetics, Manchester, 2013, pp. 4539-4542, doi: 10.1109/SMC.2013.772.

[14] Y. Wu, "A New Instance-weighting Naive Bayes Text Classifiers," 2018 IEEE International Conference of Intelligent Robotic and Control Engineering (IRCE), Lanzhou, 2018, pp. 198-202, doi: 10.1109/IRCE.2018.8492960.

[15] Lenardo, Gilang Citra, et al. Pemanfaatan Bot Telegram sebagai Media Informasi Akademik di STMIK Hang Tuah Pekanbaru. JTIM: Jurnal Teknologi Informasi dan Multimedia, 2020, 1.4: 351-357.

[16] G. Qiang, "Research and improvement for feature selection on naive bayes text classifier," 2010 2nd International Conference on Future Computer and Communication, Wuha, 2010, pp. V2-156-V2-159, doi: 10.1109/ICFCC.2010.5497362.

[17] T. Badriyah, N. A. Savitri, U. Sa'adah and I. Syarif, "Application of Naive Bayes Method for IUGR (Intra Uterine Growth Restriction) Diagnosis on The Pregnancy," 2020 International Conference on Electrical, Communication, and Computer Engineering (ICECCE), Istanbul, $\quad$ Turkey, 2020, pp. 1-4, doi: 10.1109/ICECCE49384.2020.9179256.

[18] Irawan, Yuda. Penerapan Data Mining Untuk Evaluasi Data Penjualan Menggunakan Metode Clustering Dan Algoritma Hirarki Divisive Di Perusahaan Media World Pekanbaru. Jurnal Teknologi Informasi Universitas Lambung Mangkurat (JTIULM), 2019, 4.1: 13-20.

[19] Wahyuni, Refni; IRAWAN, Yuda. Web-Based Employee Performance Assessment System in PT. Wifiku Indonesia. Journal of
Applied Engineering and Technological Science (JAETS), 2020, 1.2: 60-69.

[20] A. O. Adi and E. Çelebi, "Classification of 20 News Group with Naïve Bayes Classifier," 2014 22nd Signal Processing and Communications Applications Conference (SIU), Trabzon, 2014, pp. 2150-2153, doi: 10.1109/SIU.2014.6830688.

[21] Irawan, Yuda. Moving Load Robot Using Wifi Network and Android Based. Journal of Robotics and Control (JRC), 2020, 2.3 217-220.

[22] H. R. Seth and H. Banka, "Hardware implementation of Naïve Bayes classifier: A cost effective technique," 2016 3rd International Conference on Recent Advances in Information Technology (RAIT), Dhanbad, 2016, pp. 264-267, doi: 10.1109/RAIT.2016.7507913.

[23] Ordila, Rian, et al. Penerapan Alat Kendali Kipas Angin Menggunakan Microcontroller Arduino Mega 2560 Dan Sensor Dht22 Berbasis Android. Riau Journal Of Computer Science, 2020, 6.2: 101-106.

[24] Fonda, Hendry. Klasifikasi Batik Riau Dengan Menggunakan Convolutional Neural Networks (Cnn). Jurnal Ilmu Komputer, 2020, 9.1: 7-10.

[25] G. Aksoy and M. Karabatak, "Performance Comparison of New Fast Weighted Naïve Bayes Classifier with Other Bayes Classifiers," 2019 7th International Symposium on Digital Forensics and Security (ISDFS), Barcelos, Portugal, 2019, pp. 1-5, doi: 10.1109/ISDFS.2019.8757558.

[26] Wahyuni, Refni, Et Al. Alat Pengaman Pintu Dengan Password Menggunakan Arduino Uno At Mega 328p Dan Selenoid Door Lock. Informatika, 2020, 12.1: 51-55.

[27] B. Seref and E. Bostanci, "Sentiment Analysis using Naive Bayes and Complement Naive Bayes Classifier Algorithms on Hadoop Framework," 2018 2nd International Symposium on Multidisciplinary Studies and Innovative Technologies (ISMSIT), Ankara, 2018, pp. 1-7, doi: 10.1109/ISMSIT.2018.8567243. 